\title{
The energetic and economic analysis of outdoor temperature to enable the transition to free cooling for conditioned rooms
}

\author{
Elena Malyavina, Anastasiya Frolova \\ Moscow State University of Civil Engineering (MSUCE), Jaroslavskoe shosse 26, Moscow 129337, Russia
}

\begin{abstract}
Energy consumption of electric equipment of free cooling system can't be considered small. On the basis of multiple calculations of seasonal expenses of the electric power it is shown that expediency of transition to free cooling in Moscow conditions at external air temperature is near $+9{ }^{\circ} \mathrm{C}$. But, an economic comparison of the results found out the profit of transition to a free cooling, which shall be determined by the dry freezing agent size to be chosen for $100 \%$ of a condenser refrigeration load.
\end{abstract}

Keywords: air-conditioning; cooling machine; sensible-heat cooler; electrical energy; calculation.

\begin{tabular}{|ll|}
\hline Nomenclature \\
$t_{\text {ext }}{ }^{c}$ & outdoor air temperature $\left({ }^{\circ} \mathrm{C}\right)$ \\
$t_{\mathrm{ext}}$ & outdoor air design temperature $\left({ }^{\circ} \mathrm{C}\right)$ \\
\hline
\end{tabular}

\section{Introduction}

It is used to think, that the transition temperature from free cooling to a machine one makes $+5{ }^{\circ} \mathrm{C}$ and less. This can be explained by the fact that during the choice of a dry cooler size provision is made of its required capacity to cool a refrigeration machine condensers at $100 \%$ of its refrigeration load. The target of the work was to determine the outdoor air temperature, which enables an energetically advantageous use of water free cooling for air conditioning systems on the basis of multi-variant calculations. Besides, it seems important to find out the power consumption for free cooling and its efficiency, since usually [1] free cooling is considered as a power free one at all.

The literature examination on the subject confirmed the need of works to be provided in this field [2-4]. There is no doubt, that transition to free cooling is possible at the outdoor air temperature of $10^{\circ} \mathrm{C}$ [5] and even $13{ }^{\circ} \mathrm{C}$ [6], so the target of our work is to estimate energy and economic efficiency of such a transition.

\section{Research object}

Calculations have been provided for a three-storey office building with big heat emissions (50 W/m ${ }^{2}$ of design area), the temperature in the serviced rooms was taken $+20^{\circ} \mathrm{C}$ in the winter season and $+24{ }^{\circ} \mathrm{C}$ in the summer season. The system scheme is made of two refrigeration machines based on screw compressors with water cooled condensers, two dry coolers, two pump stations, an intermediate heat exchanger and closing fixtures (Fig. 1).

Each refrigeration machine has two screw compressor, with the capacity control from $25 \%$ and $12.5 \%$ control space from the total cold production capacity. Refrigeration machines have a liquid refrigeration condenser. The following equipment has been used: «Bitzer» compressors, «Cabero» dry coolers, «Wilo» pumps.

The selection of two refrigeration machines and the coolers is explained by a comfortable repair of the equipment. This enables $50 \%$ supply of the required load to the building from each of them. The choice of one device will lead to a total system switching off in case if an accident, and besides, the cost and the size of the equipment will be much bigger. Depending on the actual load at either free and machine cooling mode one or two dry cooler(s) may operate.

Corresponding author: Anastasiya Frolova. E-mail address: emal@list.ru

http://dx.doi.org/10.3846/enviro.2014.270

(C) 2014 The Authors. Published by VGTU Press. This is an open-access article distributed under the terms of the Creative Commons Attribution License, which permits unrestricted use, distribution, and reproduction in any medium, provided the original author and source are credited. 


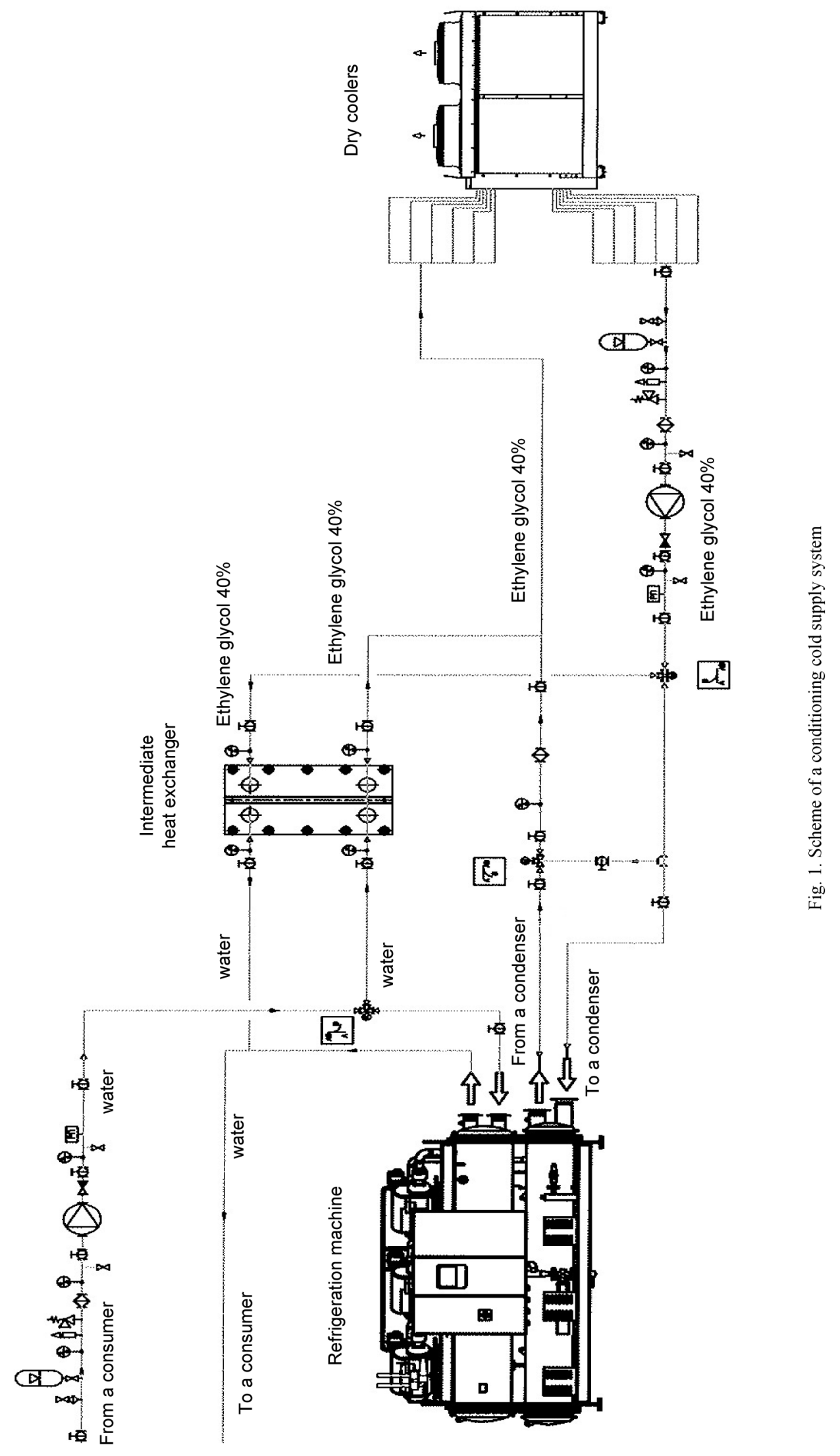


Dry coolers have two operation modes. At first, they operate as free coolers at a rather low outdoor air temperature, and at second, they operate as dry cooling towers to refrigerate the non-freezing liquid for refrigeration machine condensers. Provision was made of two types of the dry cooler surface: a) to enable the condenser refrigeration at $100 \%$ cooling load to refrigeration machines and b) to enable transition to free cooling at $+9{ }^{\circ} \mathrm{C}$ outdoor air temperature. Provision was made of three variants of the maximum outdoor air design temperature: 1) $26{ }^{\circ} \mathrm{C}$, 2) $\left.28^{\circ} \mathrm{C}, 3\right) 32{ }^{\circ} \mathrm{C}$.

The system has two loops, which come out from an intermediate heat exchanger. The first consumer loop is filled with water. Normally, for air conditioning systems provision is made of $7{ }^{\circ} \mathrm{C}-12^{\circ} \mathrm{C}$ water. But, at such a temperature range the machine cooling shall be provided up to $0{ }^{\circ} \mathrm{C}$ of the outdoor air. For a later transition to the machine cooling provision was made of $+12{ }^{\circ} \mathrm{C}$ chilled water and $+17{ }^{\circ} \mathrm{C}$ warmed water. The heat exchanger operation surface determines the maximum refrigeration capacity, which may be provided by free cooling. The adopted water temperature of $12^{\circ} \mathrm{C}-17^{\circ} \mathrm{C}$ in fan convectors (fan coils) does not lead to the air over drying in the serviced rooms, and so does not make a higher cooling load to a fan coil, though it requires a bigger fan convector. The effectiveness of the applied cold water temperature range has been confirmed in [7].

The second loop refers to the free cooling system and the condenser. This loop has a different refrigerating agent temperature (40\% ethylene glycol) at a different outdoor air temperature. The free cooling system at the declared water temperature range in the loop between the heat exchanger and the dry cooling tower shall refrigerate a non-freezing liquid up to $10{ }^{\circ} \mathrm{C}$ and be heated in the intermediate heat exchanger not higher than $15^{\circ} \mathrm{C}$. This percentage of ethylene glycol enables starting up to $-28{ }^{\circ} \mathrm{C}$ temperature in the cold season. At lower temperatures the ethylene glycol solution becomes denser and the pump can not push it up. Pump groups of the ethylene glycol loop have frequency converters. The frequency converter pumps are limited by a minimum consumption, below which they can not provide the heat-transfer agent flowing. For each pump this minimum shall be determined by a selection program. The frequency convertors of dry cooling tower fans shall be adjusted in such a way, that they can be controlled up to the rotation rate being $30 \%$ of the nominal one.

There are some approaches to the control of the evaporator consumption (in the consumer loop):

1. The fan coil consumption is controlled by the looping nodes (a three-way valve is operating), the pump is without a frequency converter.

2. Installation of a three-way control valve and pumps with a frequency converter.

3. A frequency control pump and a two-way valve.

The operation and adjustment experience of the above equipment made us to take a decision to provide the first approach using a three-way valve and pumps without a frequency converter in the consumer loop. The second approach has a big shortcoming, i.e. the three-way valve and the frequency converter try to overpower each other. In the third case the control procedure is more complicated than in the first one.

\section{Comparison of power energy indices of different variants of a cold supply unit}

So, some typical sizes of a cold supply unit shall be examined to enable refrigeration loads at different design outdoor air temperature $t_{\text {ext }}{ }^{c}$ and to provide transition to free cooling at different current outdoor air text:

- variant 1a) $\mathrm{t}_{\text {ext }}{ }^{\mathrm{c}}=26^{\circ} \mathrm{C}, \mathrm{t}_{\mathrm{ext}}=+5^{\circ} \mathrm{C}$;

- variant 1b) $\mathrm{t}_{\mathrm{ext}}{ }^{\mathrm{c}}=26^{\circ} \mathrm{C}, \mathrm{t}_{\mathrm{ext}}=+9^{\circ} \mathrm{C}$;

- variant 2a) $\mathrm{t}_{\mathrm{ext}}{ }^{\mathrm{c}}=28^{\circ} \mathrm{C}, \mathrm{t}_{\mathrm{ext}}=+5^{\circ} \mathrm{C}$;

- variant 2b) $\mathrm{t}_{\mathrm{ext}}{ }^{\mathrm{c}}=28^{\circ} \mathrm{C}, \mathrm{t}_{\mathrm{ext}}=+9^{\circ} \mathrm{C}$;

- variant 3a) $\mathrm{t}_{\mathrm{ext}}{ }^{\mathrm{c}}=32^{\circ} \mathrm{C}, \mathrm{t}_{\mathrm{ext}}=+5^{\circ} \mathrm{C}$;

- variant $3 b) \mathrm{t}_{\mathrm{ext}}^{\mathrm{c}}=32^{\circ} \mathrm{C}, \mathrm{t}_{\mathrm{ext}}=+9^{\circ} \mathrm{C}$.

Refrigeration machines, pump groups of water and ethylene glycol loops for the variants 1) and 2) are the same, because the maximum water consumption is nearly the same.

At first, the reason of a passage from free cooling to a machine one has been solved by comparison of power consumption for free cooling during the operation time of the air conditioning system at different dry cooling agent size. For this case calculations were made to determine the electrical power for all the above variants at different outdoor air temperatures.

The Results of these calculations are presented in the Appendix A (Table 1).

The electric power consumption is calculated taking into account the duration of each outdoor air temperature interval to the middle shown in the Table. In the period from the minimal temperatures text up to $\mathrm{t}_{\mathrm{ext}}=+9^{\circ} \mathrm{C}$ in the variants a) up to $+5{ }^{\circ} \mathrm{C}$ the free cooling mode is operating, and then the machine one; in the variants $b$ ) there is only free cooling.

The power consumption - in the numerator $\mathrm{kWh}$, in the denominator $\mathrm{kWh} / \mathrm{m}^{2}$ of the office area of the building under analysis - in this period for variants $1 \mathrm{a}) \mathrm{Q}=67750 / 27.41$; 1b) $\mathrm{Q}=56932 / 23.03$; 2a) $\mathrm{Q}=67731 / 27.4 ; 2 \mathrm{~b}) \mathrm{Q}=59122 / 23.92$; 3a) $\mathrm{Q}=73451 / 29.71$; 3b) $\mathrm{Q}=59880 / 24.22$.

\section{Comparison of economic indices of different cold supply unit variants}

The economic analysis of the got results was provided based on comparison of the set discounting expenses (SDE) in rubles for maintenance of the given room micro-climate at different refrigeration system variants. The SDE was calculated according to [8]. 
The lump expenses $\mathrm{K}$, rubles, for the variants of a machine and free cooling of the building include the cost of the room cooling equipment and cost of connection terms of a refrigeration system to the Moscow power supply network, which makes 40 thousand rubles for $1 \mathrm{~kW}$ of the electrical power. The cost of the equipment by variants is given in the Appendix B (Table 2), which shows, that even a small power increase of dry coolers under a $4{ }^{\circ} \mathrm{C}$ temperature rise of the outdoor air makes their cost considerably higher. Separation of the equipment, which is common for the both operation modes (dry coolers and pump groups) for the needs of free and machine cooling has been provided proportionally to the operation time of this equipment in each mode.

The operation expenses for the building cooling consist of the power cost per year and depreciation payments for the equipment use The annual operational and capital expenses for free and machine cooling systems are presented in Table 3.

Table 3. Annual operational and capital expenses for free and machine cooling

\begin{tabular}{|c|c|c|c|c|c|c|c|}
\hline 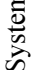 & Expenses & Variant 1a & Variant $1 b$ & Variant $2 \mathrm{a}$ & Variant $2 b$ & Variant 3a & Variant $3 b$ \\
\hline \multirow{9}{*}{ 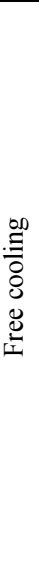 } & \multicolumn{7}{|l|}{ Operation expenses } \\
\hline & Electrical power cost, thous. rubles/year* & $106,6 / 170,02$ & $173,1 / 276,2$ & $106,57 / 170,0$ & $179,7 / 286,7$ & $113,7 / 181,47$ & $182,0 / 290,4$ \\
\hline & Depreciation payments, thous. rubles/year & 132,5 & 246,9 & 131,47 & 210,56 & 166,56 & 266,29 \\
\hline & Sum of operation expenses, thous. rubles/year* & $239,1 / 302,52$ & $420,0 / 523,1$ & $238,04 / 301,5$ & $390,3 / 497,3$ & $280,3 / 348,03$ & $448,3 / 556,7$ \\
\hline & $\begin{array}{l}\text { Sum of operation expenses, rubles/( } \\
\text { year } \mathrm{K} W \cdot h)^{*}\end{array}$ & $0,91 / 1,15$ & $1,04 / 1,30$ & $0,91 / 1,15$ & $0,97 / 1,23$ & $1,07 / 1,33$ & $1,11 / 1,38$ \\
\hline & $\begin{array}{l}\text { Sum of operation expenses, } \\
\text { rubles/(year·sq.m)* }\end{array}$ & $96,7 / 122,35$ & $185,3 / 236,1$ & $96,3 / 121,9$ & $157,9 / 201,1$ & $113,37 / 140,8$ & $181,3 / 225,2$ \\
\hline & \multicolumn{7}{|l|}{ Capital expenses } \\
\hline & Cost of equipment, rubles/( year $\kappa \mathrm{W} \cdot \mathrm{h})$ & 8,43 & 10,2 & 8,35 & 10,89 & 10,6 & 11,01 \\
\hline & Cost of equipment, rubles(sq.m) & 893,03 & 1664,3 & 885,5 & 1774,18 & 1122,76 & 1795,0 \\
\hline \multirow{11}{*}{ 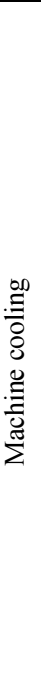 } & \multicolumn{7}{|l|}{ Operation expenses } \\
\hline & Electrical power cost, thous.rubles/year* & $426,8 / 680,9$ & $328,3 / 523,8$ & $427,5 / 682,0$ & $334,8 / 534,2$ & $444,4 / 708,9$ & $314,8 / 502,2$ \\
\hline & Depreciation payments, thous.rubles/year & 605,7 & 624,6 & 619,67 & 620,78 & 761,64 & 713,99 \\
\hline & Sum of operation expenses, thous.rubles/year* & $1032,5 / 1286,6$ & $952,9 / 1148,4$ & $1047,2 / 1301,7$ & $955,6 / 1155$ & $1206 / 1470,6$ & $1029 / 1216,2$ \\
\hline & $\begin{array}{l}\text { Sum of operation expenses, rubles/( } \\
\text { year } \mathrm{K} W \cdot h)^{*}\end{array}$ & $2,02 / 2,52$ & $2,57 / 3,1$ & $2,04 / 2,54$ & $2,57 / 3,1$ & $2,35 / 2,87$ & $2,77 / 3,27$ \\
\hline & $\begin{array}{l}\text { Sum of operation expenses, } \\
\text { rubles/(year·sq.m)* }\end{array}$ & $417,6 / 520,4$ & $385,6 / 464,75$ & $423,5 / 526,47$ & $386,5 / 467,1$ & $487,8 / 594,79$ & $416,2 / 491,9$ \\
\hline & \multicolumn{7}{|l|}{ Capital expenses } \\
\hline & Cost of equipment, thousand rubles & 5470,8 & 5431,26 & 5490,29 & 5557,07 & 6235,31 & 5793,1 \\
\hline & Sum of lump expenses, thousand rubles & 12406,8 & 12291,26 & 12746,29 & 12741,07 & 15923,31 & 14953,1 \\
\hline & Sum of lump expenses, rubles/(year'sq.m) & 30,47 & 46,01 & 31,14 & 47,46 & 38,9 & 55,68 \\
\hline & Sum of lump expense, rubles/(sq.m) & 5017,96 & 5217,13 & 5155,27 & 5153,15 & 6440,22 & 6047,8 \\
\hline
\end{tabular}

*Note: in the fraction numerator the value is shown for the electrical power price of $3.04 \mathrm{ruble} / \mathrm{kWh}$, in the denominator - of $4.85 \mathrm{ruble} / \mathrm{kWh}$.

Comparison of the set discounting expenses (SDE) was made for the round-year provision of the cooling load (free and machine refrigeration in its outdoor air temperature range). The summarized capital and operation expenses by variants are given in the Table 3, and the SDE change curves within the first 15 operation years of the system are given in Fig. 2. 


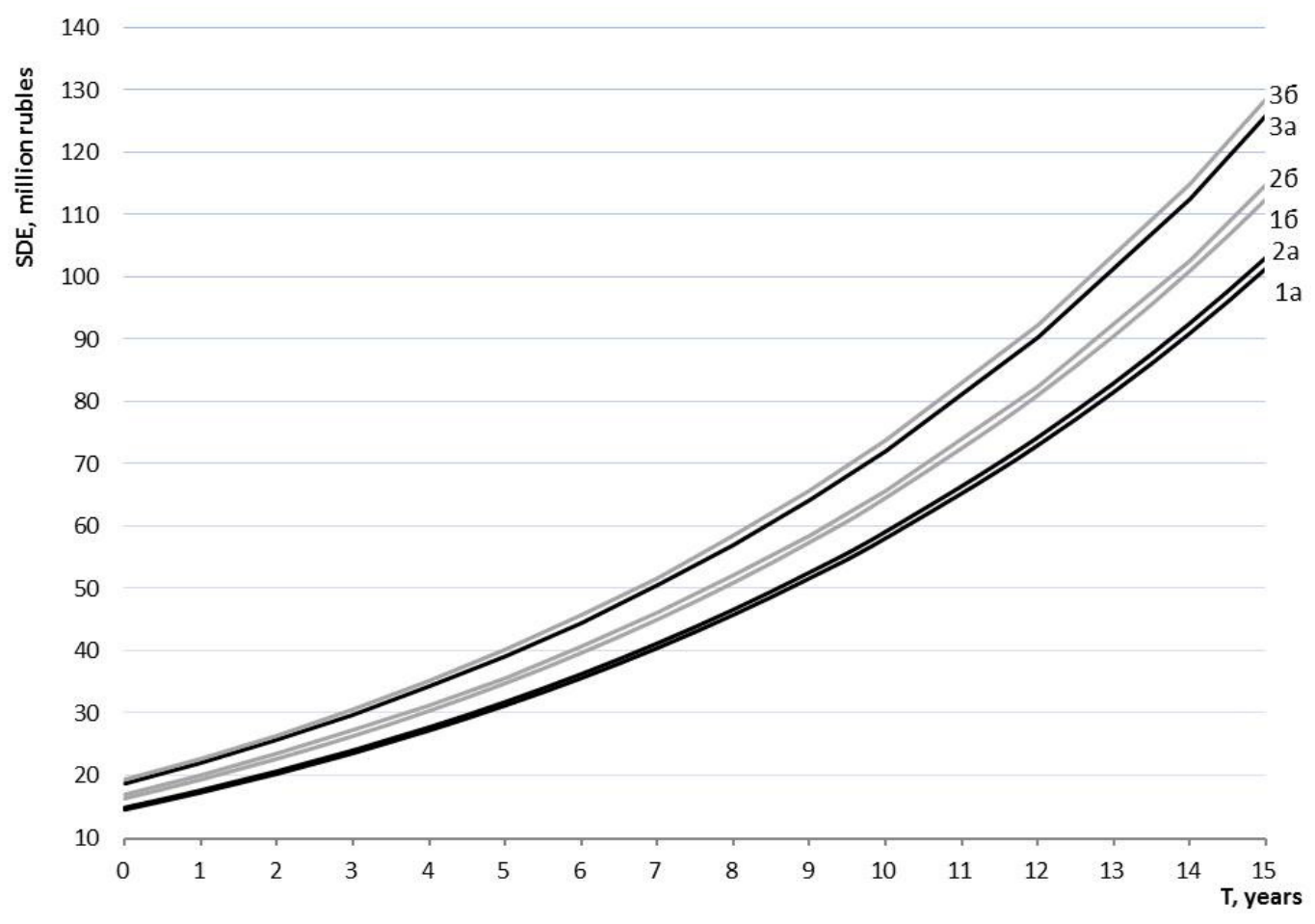

Fig. 2. Scheme of a conditioning cold supply system

Fig. 2 shows, that if a refrigeration machine is chosen as a cooling load provider, being determined by the design outdoor air temperature in the warm period of the year from $26^{\circ} \mathrm{C}$ to $32{ }^{\circ} \mathrm{C}$, transition to free cooling is more profitable from the economic point of view based on the dry cooler size to be chosen for $100 \%$ load of the condenser cooling., Increase of a dry cooler size is not profitable. It is interesting, that if the design outdoor air temperature is increased to choose a refrigeration machine, the difference in SDE for the variants a) and b) becomes smaller.

\section{Conclusions}

1. The calculation results given in the Appendix A. show, that the free cooling system power, which is consumed by the electrical equipment, shall not be considered as negligible one. At a higher outdoor air temperature it increases considerably at th close to the transition limit to the machine refrigeration and approach to the consumed power of the machine cooling.

2. The calculations confirmed a widely used opinion, that a transition to a machine refrigeration with dry coolers, which provide a $100 \%$ load of the refrigeration machine, takes place at $\mathrm{t}_{\mathrm{ext}}=+5^{\circ} \mathrm{C}$. This dry cooler operates in the free cooling mode during the heating season with a better conversion coefficient than a bigger cooler, which has been chosen for transition to the machine refrigeration at $\mathrm{t}_{\mathrm{ext}}=+9^{\circ} \mathrm{C}$. But a bigger cooler leads to a bigger conversion coefficient when provision is made of the machine refrigeration in the warm period of the year.

3. The given electrical power consumption values of the cooling systems to provide $+12-+17^{\circ} \mathrm{C}$ water for the period from a negative air temperature to $+9{ }^{\circ} \mathrm{C}$ let us to make a conclusion, that the transition to a machine cooling at a higher outdoor temperature $\mathrm{t}_{\mathrm{ext}}=+9^{\circ} \mathrm{C}$ is more advantageous from the power point of view, than a transition at $\mathrm{t}_{\mathrm{ext}}=+5^{\circ} \mathrm{C}$.

4. The consumed electrical power for a machine refrigeration depends considerably on the outdoor air temperature, since first of all the load changes for cooling of the incoming air itself, and then when the outdoor air becomes higher the liquid temperature lowering conditions become worse for the condenser refrigeration. That is why, the electric power consumption for operation of a refrigeration machine grow up sharply at the design outdoor air temperature in the warm season of the year.

5. From the economic point of view the increase of a dry cooler is not profitable, because a small increase of the dry cooler power increases greatly their price. Transition to free cooling is more advantageous economically being determined by the dry cooler size, which has been chosen for $100 \%$ of the condenser cooling load. If the dry cooler price is made lower, it seems to be profitable to make them bigger.

6. In economic comparisons we can not ignore the cost of the year power consumption by the free cooling system, since it makes an important part (20\%-60\%) of the annual power consumption cost of the machine cooling.

7. Attention shall be put on the fact, that due to a high price of the equipment the depreciation expenses make more than $50 \%$ of the annual cost of the electric power and may increase to $90 \%$ of it. It is important, that the price of connection to the building cooling power line networks exceeds the price of an expensive cooling equipment, taking into account, that for Moscow the power line connection cost makes $40000 \mathrm{rubles} / \mathrm{kW}$. 


\section{References}

[1] Наумов, А. Л. 2009. Оценка и роль теплозащиты общественных зданий, АВОК 7: 30-36 / Naumov A. L. 2009. Assessment and role of thermal protection of public buildings, $A B O K$ 7: 30-36.

[2] Moser, D. 2011. Free Cooling: Don't Let Saving Slip Away, Building Operating Management 8: 65-70.

[3] Arkar, C.; Medved, S. 2007. Free-cooling of a building using PCM heat storage integrated into the ventilation system, Solar Energy 81(9): 1078-1087. http://dx.doi.org/10.1016/j.solener.2007.01.010

[4] Zalba, B.; Marin, J. M.; Cabeza, L. F.; Mehling, H. 2004. Free-cooling of buildings with phase changematerials, Int. Journal of Refrigeration 27(8): 839-849. http://dx.doi.org/10.1016/j.ijrefrig.2004.03.015

[5] Шишов, В.В.; Козлов, М. Ю. 2011. Система «свободного охлаждения» (Free Cooling). COK 10, c. 3-45 / V. Shishov, M. Klokov. 2011. “Free Cooling" System. SOK 10, p. 38-45.

[6] Рожин, П. Л.; Шеин, Е. В. 2012. Анализ технических решений по использованию свободного охлаждения (фрикулинга) на базовых станциях сотовой связи. Вестник УКЦ АПИК 30: 17 -22 / Р. Rozhin, E.Shein. 2012. The analysis of technical solutions to use free cooling on base stations of cellular communication. Bulletin of UKTs APIK 30: 17-22.

[7] Рубцов, А. С. 2012. Повышение энергоэффективности инженерных систем торгово-развлекательных центров. АВOК 8: / Rubtsov A.S. 2012. Improvement of energy efficiency of engineering systems in trade and entertrainmjent centers. $A B O K$ 8:26-33.

[8] Гагарин, В.Г. 2010. Макроэкономические аспекты обоснования энергосберегающих мероприятий при повышении теплозащиты ограждающих конструкций зданий. Строительные материаль 3: 8-16 / Gagarin V.G. 2010. Macro-economic aspects of justification to provide power saving measures at a higher thermal protection of enclosing structures of public buildings, Construction materials 3: 8-16. 


\begin{tabular}{|c|c|c|c|c|c|c|c|c|c|c|c|c|c|c|c|c|c|c|c|c|}
\hline & & 郭 & & 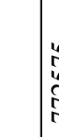 & $\begin{array}{c}n \\
\text { E } \\
E\end{array}$ & & & & & 誉 & & & & 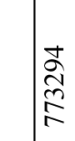 & & & & & 章 & \\
\hline & $\tilde{m}$ & - & & 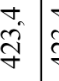 & â & & 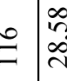 & 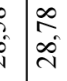 & $\stackrel{\infty}{\Xi}$ & $\mid \begin{array}{l}\infty \\
\stackrel{\infty}{\Xi} \\
\end{array}$ & & $\stackrel{n}{\sim}$ & & 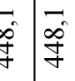 & & $\stackrel{\varrho}{=}$ & 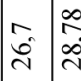 & 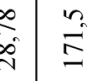 & $\underline{I}$ & $\stackrel{0}{i}$ \\
\hline & $\underset{c \rightarrow}{\infty}$ & $\widehat{c}$ & & \begin{tabular}{c|c}
$\vec{a}$ & $\vdots$ \\
$\vec{q}$ & $\vdots$
\end{tabular} & & & $=\mid \begin{array}{l}\infty \\
= \\
\infty \\
\infty \\
0\end{array}$ & 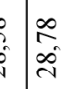 & $\stackrel{\infty}{=}$ & $\mid \begin{array}{l}\mid \hat{o} \\
\delta\end{array}$ & & बे & $\begin{array}{l}\infty \\
\text { in } \\
\text { in }\end{array}$ & 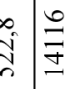 & & $\cong$ & 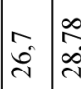 & 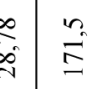 & $\vec{s}$ & $m$ \\
\hline & $\underset{\sim}{2}$ & $\Phi$ & & \begin{tabular}{l|l}
$\hat{n}$ & $\vdots$ \\
$i n$ & $y$
\end{tabular} & & & $\underset{U}{U}$ & $\hat{i}$ & $\frac{a}{E}$ & 表 & & $\bar{m}$ & & 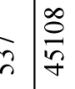 & & $\cong$ & 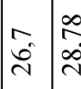 & 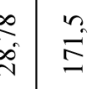 & 导 & $\bar{m}$ \\
\hline & ㄱ. & 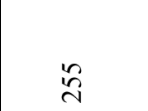 & & 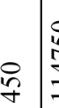 & & & $\vec{\infty}$ & î & $\begin{array}{l}a \\
0 \\
0 \\
0\end{array}$ & 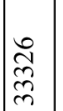 & & $\stackrel{\vec{r}}{m}$ & & 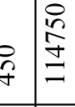 & $\frac{00}{5}$ & $\vec{\infty}$ & 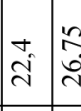 & $=$ & $\bar{m}$ & $\vec{m}$ \\
\hline 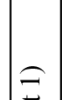 & $\cong$ & ֶి & & 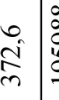 & $\begin{array}{l}\infty \\
0 \\
2 \\
2 \\
2\end{array}$ & & $\begin{array}{ll}0 \\
0 \\
0\end{array}$ & 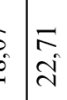 & $\begin{array}{l}a \\
\dot{a} \\
\dot{a}\end{array}$ & 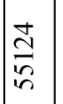 & & i & & 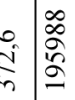 & 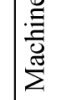 & t & 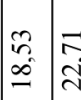 & 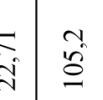 & 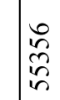 & $\stackrel{n}{m}$ \\
\hline $\begin{array}{l}\sum^{\infty} \\
\varrho \\
\Xi\end{array}$ & $a$ & m & i & $\begin{array}{ll}- & 5 \\
\bar{m} & \end{array}$ & م. & 要 & 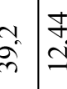 & in & $\stackrel{m}{r}$ & 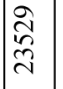 & & $\stackrel{\sim}{\sim}$ & 永 & $\begin{array}{l}= \\
\bar{n} \\
n=\end{array}$ & & 1 & \begin{tabular}{l|l}
$\infty$ & 3 \\
$\infty$ & 0 \\
$\infty$ & 0
\end{tabular} & a. & ల్ర్ & $\tilde{n}$ \\
\hline 竞 & r & 䓌 & 言 & 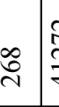 & $\frac{\mathrm{y}}{\mathrm{y}}$ & 竧 & \begin{tabular}{c|c}
$d$ \\
$\stackrel{d}{m}$ & $\infty$ \\
$\infty$ & $\infty$
\end{tabular} & $\dot{0}$ & $\begin{array}{l}\bar{n} \\
\text { in }\end{array}$ & $\frac{n}{6}$ & & $\stackrel{n}{*}$ & 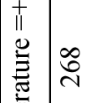 & 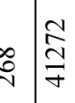 & & 1 & $\vec{a} \mid \begin{array}{l}\infty \\
\infty\end{array}$ & 㐫 & 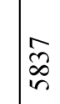 & $\vec{\pi}$ \\
\hline 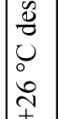 & in & สี & 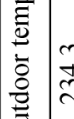 & 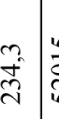 & 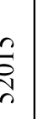 & & $\begin{array}{ll}0 \\
1 \\
\\
\end{array}$ & $\begin{array}{l}\infty \\
\dot{0} \\
\infty \\
\infty\end{array}$ & $\begin{array}{l}\tilde{\infty} \\
\hat{i} \\
\tilde{m}\end{array}$ & 离 & & $\bar{n}$ & 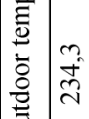 & 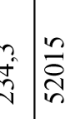 & & 1 & 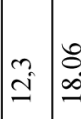 & 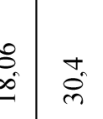 & $\frac{9}{6}$ & $\approx$ \\
\hline 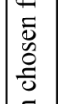 & 0 & in & 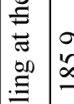 & 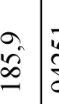 & $\frac{6}{2}$ & & $1 \mid \frac{m}{3}$ & $\begin{array}{l}0 \\
0 \\
0 \\
0\end{array}$ & $\begin{array}{c}\tilde{\sigma} \\
\text { jे }\end{array}$ & $\mid \frac{n}{a}$ & & $\stackrel{\infty}{\sim}$ & 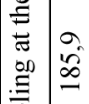 & \begin{tabular}{c|c}
$\overline{2}$ \\
0 \\
0 \\
0
\end{tabular} & & 1 & \begin{tabular}{|l|l} 
\\
D \\
in
\end{tabular} & \begin{tabular}{c|c}
0 \\
0 \\
0 \\
0
\end{tabular} & 佲 & $\tilde{\infty}^{1}$ \\
\hline 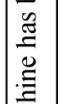 & $n$ & 옹 & 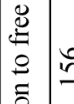 & 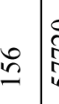 & $\frac{c}{n}$ & & $1 \overline{\mathcal{F}}$ & 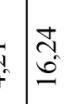 & in & în & & $\stackrel{6}{r}$ & & : & & 1 & 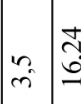 & 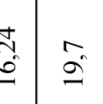 & 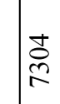 & $\stackrel{2}{\therefore}$ \\
\hline $\mid$ & $\stackrel{\odot}{1}$ & $\overline{\mathrm{\lambda}}$ & 产 & 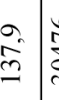 & 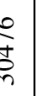 & & 1 & 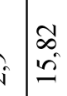 & $\frac{-}{\mathbb{\infty}}$ & $\stackrel{\widehat{m}}{\xi}$ & & $\stackrel{\vec{r}}{\sim}$ & & 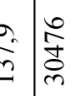 & & 1 & \begin{tabular}{|l|l}
$F_{i}$ & $\infty$ \\
$i$ & 0
\end{tabular} & $\begin{array}{l}\infty \\
\infty \\
\infty\end{array}$ & ठे & $\stackrel{\circ}{\sim}$ \\
\hline$\stackrel{\mathscr{E}}{E}$ & $\stackrel{n}{1}$ & $\cong$ & & $\bar{\Xi}$ & $\begin{array}{c}n \\
0 \\
0 \\
c \\
n\end{array}$ & & $\mid \frac{\infty}{\pi}$ & $\begin{array}{c}0 \\
\dot{0} \\
\hat{i}\end{array}$ & $\stackrel{\vec{\Delta}}{=}$ & \begin{tabular}{|l|}
$\infty$ \\
$\underset{\mathbf{z}}{\mathbf{z}}$
\end{tabular} & & $\stackrel{\approx}{r}$ & $\hat{\beth}$ & 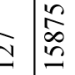 & & 1 & \begin{tabular}{|l|l} 
& 0 \\
0 & 0 \\
$-\infty$ & $n$ \\
-1
\end{tabular} & 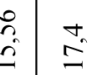 & $\stackrel{\frac{N}{2}}{\sim}$ & $\stackrel{m}{n}$ \\
\hline & $\stackrel{\text { }}{\top}$ & 8 & & 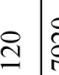 & 2 & & 1 & 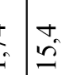 & $\begin{array}{l} \pm \\
\Xi\end{array}$ & $\overrightarrow{\underline{m}}$ & & r & & ত্ত & & 1 & 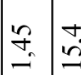 & $\begin{array}{c}\vec{b} \\
\hat{n}\end{array}$ & $\Xi$ & $\vec{\therefore}$ \\
\hline & $\stackrel{1}{i}$ & ส & & \pm & to & o & I & 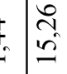 & $\underline{6}$ & $\mid \begin{array}{l}\Delta \\
\overrightarrow{0} \\
\stackrel{0}{0}\end{array}$ & & $\begin{array}{l}\infty \\
0^{0}\end{array}$ & & 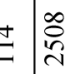 & & 1 & 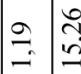 &  & d్ల & $\hat{\sigma}$ \\
\hline & $\stackrel{\infty}{\uparrow}$ & $\simeq$ & & $\begin{array}{ll}m \\
\overrightarrow{0}\end{array}$ & $\begin{array}{c}0 \\
0 \\
0 \\
0 \\
0.1\end{array}$ & 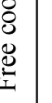 & $1 \stackrel{2}{1}$ & $\sqrt{5}$ & 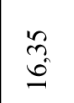 & 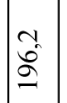 & & 0 & & $\begin{array}{ll}2 \\
2 \\
\vdots \\
2\end{array}$ & 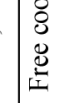 & I & $\begin{array}{ll}0 & \bar{n} \\
0 & -1\end{array}$ & $\stackrel{t}{\overrightarrow{0}}$ & $g$ & $\stackrel{0}{0}_{0}^{\circ}$ \\
\hline & 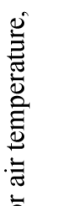 & 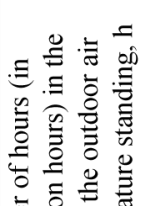 & & 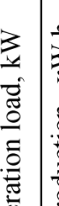 & 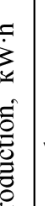 & 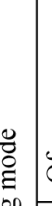 & 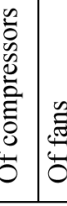 & 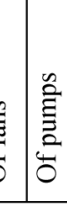 & 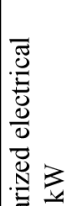 & 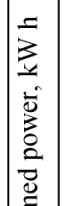 & 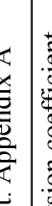 & 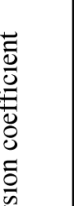 & & 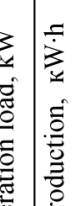 & $\stackrel{8}{8}$ & 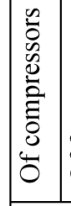 & 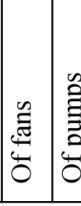 & 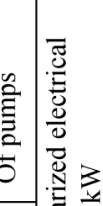 & 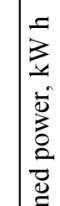 & 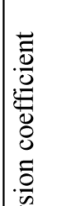 \\
\hline & 0 & 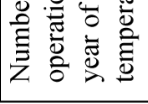 & $\bigsqcup^{2}$ & 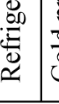 & 这 & 咅 & 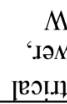 & & 莬蒂 & 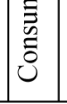 & 5 & . & 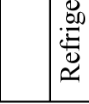 & 焉 & 寻 & & 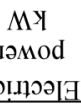 & 日 & 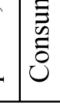 & 这 \\
\hline
\end{tabular}




\begin{tabular}{|c|c|c|c|c|c|c|c|c|c|c|c|c|c|c|c|c|c|c|}
\hline & 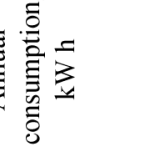 & & 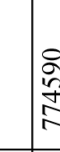 & & & & & & 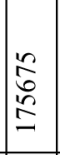 & & & 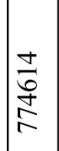 & & & & & 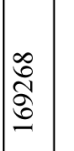 & \\
\hline లు & - & 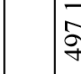 & $\overline{7}$ & & $\Xi$ & 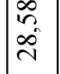 & 我 & $\stackrel{\vec{\infty}}{\vec{\infty}}$ & $\bar{\infty}$ & $\hat{i}$ & $\begin{array}{l}\infty \\
0 \\
i n \\
\text { in }\end{array}$ & $\bar{i}$ & & 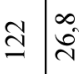 & 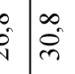 & 品 & $\nsubseteq$ & iे \\
\hline$\stackrel{\infty}{\sim}$ & $\bar{\sim}$ & ic & 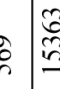 & & $\mathbb{Z}$ & \begin{tabular}{|l|}
$\infty$ \\
$\infty$ \\
$\infty$ \\
$\infty$ \\
$\infty$
\end{tabular} & $\begin{array}{l}\infty \\
\hat{n} \\
\hat{n}\end{array}$ & $\stackrel{\vec{\Phi}}{\stackrel{\vec{\infty}}{\Delta}}$ & $\mid \begin{array}{l}\infty \\
\dot{\infty} \\
\dot{q}\end{array}$ & $\vec{m}$ & 总 & $\mid \begin{array}{l}0 \\
\tilde{n} \\
\end{array}$ & & I & 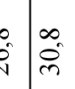 & $\begin{array}{l}0 \\
\stackrel{2}{I}\end{array}$ &  & $\stackrel{\vec{m}}{m}$ \\
\hline$i$ & $\Phi$ & i & 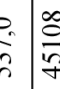 & & $\stackrel{\bullet}{=}$ & $\hat{\sim}$ & $\begin{array}{l}\infty \\
\infty \\
\infty \\
\infty\end{array}$ & $\stackrel{\infty}{\stackrel{\infty}{\Xi}}$ & 䙳 & $\vec{m}$ & in & $\mid \begin{array}{c}\infty \\
\frac{8}{n g} \\
\frac{n}{q}\end{array}$ & & 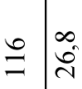 & 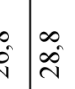 & $\stackrel{0}{\stackrel{0}{E}}$ & $\frac{m}{z}$ & $\bar{m}$ \\
\hline त् & 芳 & 5 &  & & $\frac{a}{\infty}$ & $\tilde{\Theta}$ & 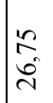 & $\overrightarrow{\hat{m}}$ & $\vec{m}$ & $\stackrel{\vec{m}}{m}$ & in & 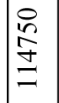 & $\mid \stackrel{00}{\underline{E}}$ & 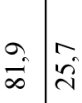 & 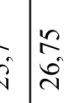 & $\begin{array}{l}+ \\
\stackrel{+}{d} \\
\stackrel{d}{*}\end{array}$ & 突 & $\ddot{m}$ \\
\hline$\stackrel{n}{2}$ & in & 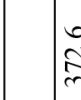 & 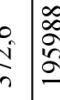 & & t & \begin{tabular}{|l}
0 \\
0 \\
$\underline{\infty}$
\end{tabular} & $\begin{array}{l}\mathbb{Z} \\
\hat{\sim}\end{array}$ & $\begin{array}{l}\infty \\
\stackrel{0}{\Xi}\end{array}$ & $\mid \vec{i}$ & ri & 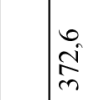 & $\begin{array}{l}\infty \\
\infty \\
0 \\
0 \\
\varrho \\
0\end{array}$ & $\mid$ & \begin{tabular}{l|l} 
& 0 \\
\end{tabular} & $\begin{array}{l}\dot{b} \\
\dot{b}\end{array}$ & $\stackrel{m}{\stackrel{2}{0}}$ & 售 & $\stackrel{6}{i}$ \\
\hline$a$ & ల్లి & $\bar{c}$ & 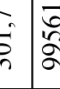 & $\frac{3}{8}$ & ळे & $\begin{array}{l}\mathbb{Z} \\
\mathrm{I} \\
\mathbf{I}\end{array}$ & $\begin{array}{l}3 \\
2\end{array}$ & $\stackrel{\widehat{ }}{\gtrless}$ & $\begin{array}{l}\frac{a}{n} \\
\hat{\sim} \\
\hat{\sim}\end{array}$ & $\stackrel{\sim}{F}$ & : & \begin{tabular}{l}
$\overline{0}$ \\
\hdashline \\
$\alpha$
\end{tabular} & & $1 \stackrel{m}{m}$ & 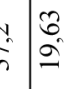 & $\stackrel{\infty}{\stackrel{0}{n}^{n}}$ & $\mid$ & n. \\
\hline$r$ & 志 & 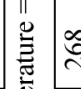 & 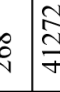 & 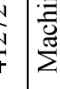 & $\frac{\vec{m}}{m}$ & $\mid \begin{array}{l}\infty \\
\infty \\
\infty \\
\infty\end{array}$ & $\approx$ & $\begin{array}{l}\text { ñ } \\
\text { on }\end{array}$ & $\frac{n}{\sigma}$ & $\stackrel{n}{\prime}$ & 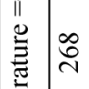 &  & & $1 \mid \frac{\vec{N}}{1}$ & $\begin{array}{ll}\infty \\
-\infty \\
\infty\end{array}$ & $\stackrel{\infty}{\infty}$ & $\frac{d}{0}$ & $\hat{\sigma}$ \\
\hline in & สี & 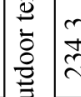 & & & 1 & $\begin{array}{l}\stackrel{0}{2} \\
\pm \\
\pm\end{array}$ & 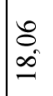 & $\begin{array}{l}\text { D. } \\
\text { î } \\
\text { d. }\end{array}$ & 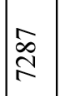 & $\vec{\pi}$ & 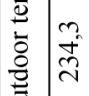 & 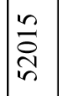 & & $\begin{array}{l}1 \\
1 \\
\end{array}$ & 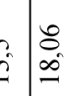 & $\frac{n}{m}$ & हैं & $\stackrel{\Delta}{\sim}$ \\
\hline 0 & in & 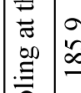 & & & 1 & $\begin{array}{l}0 \\
\therefore \\
r\end{array}$ & बे & $\begin{array}{l}\hat{\alpha} \\
\hat{a}\end{array}$ & $\frac{\approx}{\cong}$ & $\stackrel{\infty}{\sim}$ & 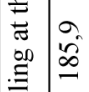 & $\begin{array}{l}\vec{z} \\
\frac{a}{\alpha}\end{array}$ & & , & $\begin{array}{l}y_{1} \\
0 \\
0\end{array}$ & $\ddot{\vec{d}}$ & 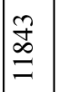 & $\infty$ \\
\hline ip & i & 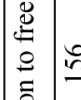 & 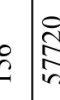 & & 1 & $\bar{F}$ & 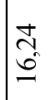 & 学 & $\mid \begin{array}{l}\infty \\
\stackrel{0}{*} \\
\stackrel{n}{n}\end{array}$ & $\stackrel{0}{i}$ & 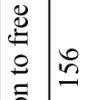 & 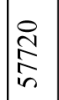 & & $\mid \begin{array}{l}\infty \\
\infty \\
\infty \\
n\end{array}$ & $\begin{array}{ll}6 \\
0 \\
i\end{array}$ & $\overrightarrow{\mathrm{N}}$ & 焉 & $\stackrel{\infty}{r}$ \\
\hline$\stackrel{\odot}{1}$ & $\overrightarrow{\mathbb{N}}$ & 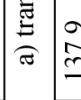 & $\frac{1}{2}$ & & 1 & $\overrightarrow{\hat{i}}$ & 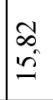 & 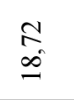 &  & 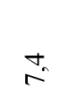 & 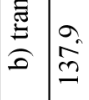 & $\mid \begin{array}{l}0 \\
0 \\
0 \\
0 \\
0\end{array}$ & & $\mid \begin{array}{l}8 \\
0\end{array}$ & 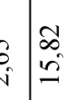 & $\stackrel{n}{\infty}$ & $\mid \begin{array}{l}\bar{o} \\
\dot{q}\end{array}$ & $\stackrel{n}{\sim}$ \\
\hline$\frac{n}{1}$ & $\cong$ & $\nexists$ & $\underline{y}$ & & 1 & $\begin{array}{l}\infty \\
\frac{\infty}{i}\end{array}$ & $\begin{array}{l}0 \\
n \\
n \\
n \\
2\end{array}$ & $\stackrel{+}{\stackrel{\Xi}{\leftrightarrows}}$ & $\frac{\infty}{\mathbb{N}}$ & $\stackrel{2}{2}$ & 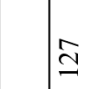 & $\mid \begin{array}{c}n \\
\infty \\
\infty \\
n \\
n\end{array}$ & & 12 & 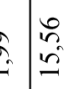 & 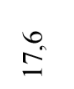 & $\frac{\pi}{2}$ & $\stackrel{2}{\sim}$ \\
\hline ते & 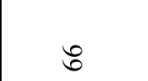 & $\cong$ & $\begin{array}{l}2 \\
\end{array}$ & & 1 & $\stackrel{ \pm}{ \pm}$ & $\stackrel{E}{2}$ & $\begin{array}{l}\stackrel{ \pm}{I} \\
\Xi\end{array}$ & $\hat{\varrho}$ & r & 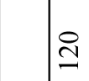 & 交 & & 12 & 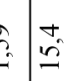 & $=$ & $\Xi$ & $\vec{r}$ \\
\hline î & ה & $\Xi$ & 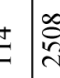 & 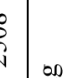 & 1 & $\underset{-}{ \pm}$ & 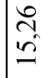 & $\widehat{\widehat{6}}$ & $\mid \begin{array}{l}2 \\
\vdots \\
0 \\
0 \\
n\end{array}$ & $\overbrace{0}^{\infty}$ & $\Xi$ & $\mid \begin{array}{l}\infty \\
0 \\
0 \\
a \\
a\end{array}$ & & $\mathrm{~m}$ & 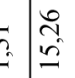 & م. & $\mid$ & $\hat{\sigma}^{\circ}$ \\
\hline ণి & $\simeq$ & $\frac{5}{5}$ &  & $\begin{array}{ll}0 \\
0 \\
0 \\
0 \\
0\end{array}$ & 1 & $\cong$ & $\overline{2}$ & $\begin{array}{l}10 \\
3 \\
0 \\
0\end{array}$ & 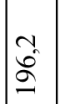 & ర. & $\frac{m}{a}$ & 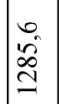 & 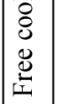 & 1 & $\overrightarrow{\vec{n}} \overrightarrow{\vec{n}}$ & \begin{tabular}{l}
\multirow{J}{*}{} \\
ó
\end{tabular} & $\stackrel{\sigma}{\sigma}$ & $\mathbb{O}_{0}^{0}$ \\
\hline 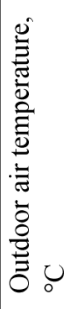 &  & 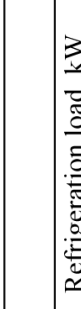 & 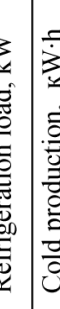 & 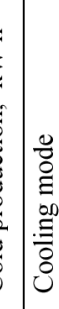 & 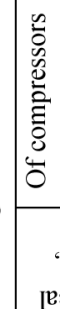 & 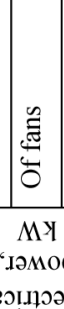 & $\begin{array}{l}\text { 产 } \\
\text { 言 } \\
\text { 足 }\end{array}$ & 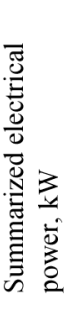 & 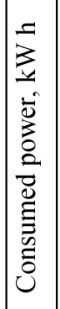 & 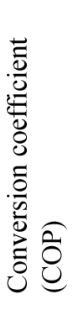 & 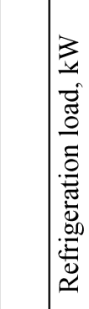 & 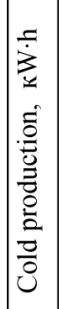 &  & 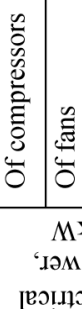 & 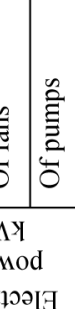 & 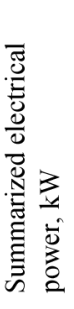 &  & 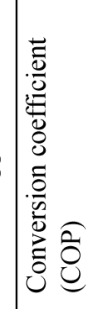 \\
\hline
\end{tabular}




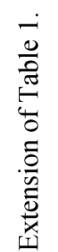

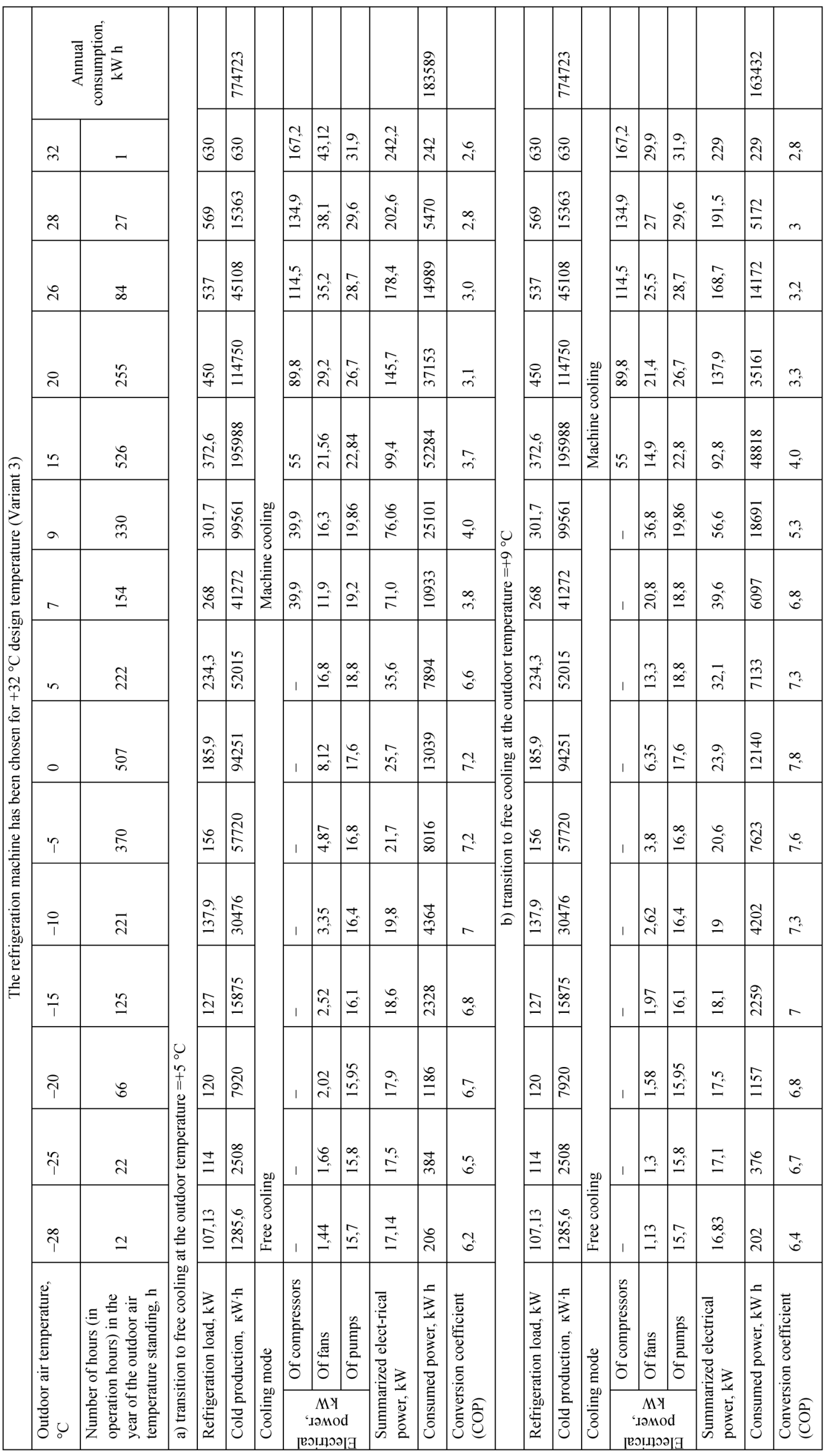




\section{Apendix B}

Table 2. Cost of equipment for the air cooling system, thousand rubles (in numerator) and thousand rubles per $1 \mathrm{~m}^{2}$ (in denominator)

\begin{tabular}{|l|l|l|l|l|l|l|}
\hline \multirow{2}{*}{ Equipment } & \multicolumn{4}{|c|}{ Variants } \\
\cline { 2 - 6 } & $1 \mathrm{a}$ & $1 \mathrm{~b}$ & $2 \mathrm{a}$ & $2 \mathrm{~b}$ & $3 \mathrm{~b}$ \\
\hline Refrigeration machines & $2966,88 / 1,2$ & $2966,88 / 1,2$ & $2966,88 / 1,2$ & $2966,88 / 1,2$ & $3139,72 / 1,27$ & $3139,72 / 1,27$ \\
\hline Dry coolers & $2023,36 / 0,82$ & $3531,92 / 1,43$ & $2023,36 / 0,82$ & $3852,57 / 1,56$ & $2896,72 / 1,17$ & $3877,36 / 1,57$ \\
\hline Pump units & $1116,4 / 0,45$ & $1116,4 / 0,45$ & $1116,4 / 0,45$ & $1116,4 / 0,45$ & $1152,4 / 0,47$ & $1152,4 / 0,47$ \\
\hline Heat exchanger at free cooling & $134,48 / 0,05$ & $145,2 / 0,059$ & $134,48 / 0,05$ & $145,2 / 0,059$ & $134,48 / 0,05$ & $145,2 / 0,059$ \\
\hline
\end{tabular}

